\title{
Study on the water stability of asphalt mixture under the action of sulfite on saline zone in Tarim basin
}

\author{
Zheng Yu-xin,Lli chun-yan \\ (Xinjiang Vocational and Technical College of Communications, Xinjinag Urumqi 831401 ) \\ (Xinjiang Industy Technical College ,Xinjinag Urumqi 830021)
}

KEY WORDS: salinized soil ; sulfite; asphalt mixture; water stability

ABSTRACT: The of sansha highway on saline soil area in Tarim basin, soak the formed asphalt mixture in a salt solution for 60 hours, Immersing Marshall test and freeze-thaw split test respectively, system analysis of test data, It is concluded that the asphalt pavement in the saline soil is the long-term erosion of sulfate study, the water stability of asphalt pavement is seriously damaged.

\section{Foreword}

The methods to evaluate the water stability of asphalt mixture include static load test, immersion Marshall test, immersion compressive strength test, split tensile strength test, and improved Lottman method, that is, freeze-thaw splitting test. The most typical method of dynamic load test is the immerseable rutting test and the immersion loop test. They are the engineering test methods which try to simulate the actual conditions in the field. In this study, the immersion Marshall test and freeze-thaw splitting test in "Highway Engineering Asphalt and Asphalt Mixture Test Rules" were used to test the water stability of asphalt mixture specimens. Both methods adopt the compaction method to form the cylindrical specimens, 75 times of positive and negative compaction were used in Marshall immersion test, and 50 times of positive and negative compaction were used in freeze-thaw splitting test.

\section{Immersion Marshall Test and Analysis}

The difference between the immersion Marshall test method and the standard Marshall test (JTJ 0709-2000) method is that the temperature holding time of the specimen in the constant temperature tank is $48 \mathrm{~h}$, and the rest are the same as the standard Marshall test method.

The stability of immersion residue of the specimen is calculated by the following formula: $M \mathrm{~s}_{0}=\frac{M \mathrm{~s}_{1}}{M \mathrm{~s}} \times 100$

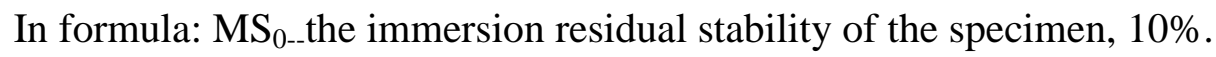

MS:--the stability of the specimen after being immersed in water for 48 hours, $\mathrm{KN}$.

The Marshall modulus of the specimen is calculated by the following formula:

$$
\mathrm{T}=\frac{M \mathrm{~s}}{\mathrm{FL}}
$$

In formula: T-- Marshall modulus of the specimen, $\mathrm{KN} / \mathrm{mmmm}$.

$$
\begin{aligned}
& \text { MS--specimen stability, } \mathrm{KN} \text {; } \\
& \text { FL--the flow value of the specimen, } \mathrm{mm} \text {. }
\end{aligned}
$$

The residual stability of asphalt concrete is required higher than $80 \%$, which is used to evaluate the adhesion between asphalt and aggregate in water for a long time.

For the special test of this part, the formed specimen was first immersed in salt solution for 60 hours in natural environment, and then placed in the room for about 12 hours. The test was carried 
out according to the test rules. The influence degree of salt on the water stability of asphalt mixture is analyzed. The test results are shown in Table 1.

Table 1 Summary of test results

\begin{tabular}{|c|c|c|c|c|c|c|}
\hline & & $\begin{array}{c}\text { Stability } \\
(\mathrm{KN})\end{array}$ & $\begin{array}{c}\text { Flow value } \\
(0.1 \mathrm{~mm})\end{array}$ & $\begin{array}{c}\text { Stability } \\
\text { after } 48 \text { h } \\
\text { immers }\end{array}$ & $\begin{array}{c}\text { Flow value } \\
(0.1 \mathrm{~mm})\end{array}$ & $\begin{array}{c}\text { Residual } \\
\text { stability } \\
(\%)\end{array}$ \\
\hline \multicolumn{2}{|c|}{ Routine } & 13.33 & 4.48 & 11.66 & 5.01 & 87.47 \\
\hline \multirow{4}{*}{ 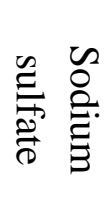 } & $3 \%$ & 12.86 & 4.89 & 10.76 & 5.57 & 83.67 \\
\hline & $6 \%$ & 12.5 & 4.72 & 11.0 & 5.64 & 88.0 \\
\hline & $10 \%$ & 11.48 & 5.64 & 9.63 & 5.98 & 83.89 \\
\hline & $15 \%$ & 11.14 & 5.52 & 9.84 & 6.42 & 88.33 \\
\hline
\end{tabular}

In combination with figure 1 and figure 2 , it can be seen that both the stability and the flow value are affected by sulfate.

1) When the mixture specimen is not eroded by sulfate, the stability before and after immersion is relatively high, and the residual stability also meets the standard requirements.

2) With the increase of sulfate concentration, the stability becomes smaller, and the flow value increases with the increase of sulfate concentration, generally speaking, there is an increasing trend, which is also a reference information that can not be ignored.

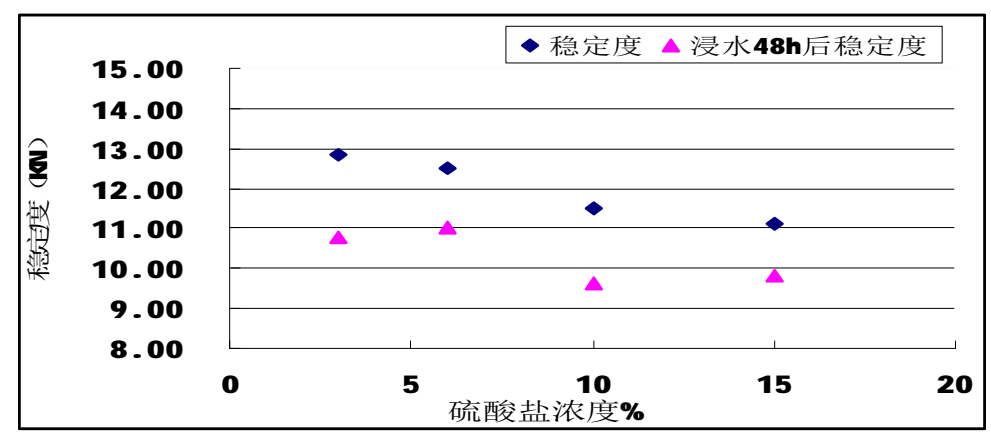

Fig. 1 Relationship between stability and sulfate concentration

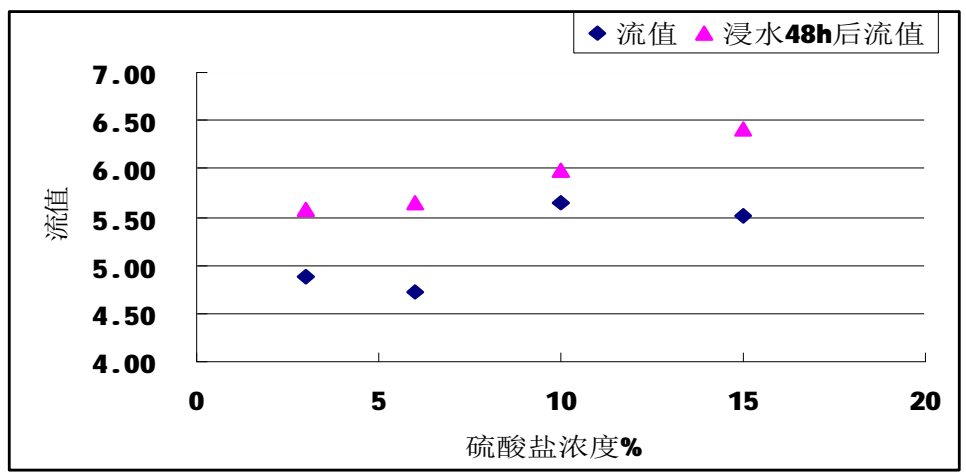

Fig. 2 Relationship between flow value and sulfate concentration

\section{Freeze-thaw splitting Test and Analysis}

Freeze-thaw splitting test is a simplified Lottman test.

The evaluation index of water stability of asphalt mixture is to retain the residual stability index of $48 \mathrm{~h}$ immersion Marshall test, and to evaluate the water stability by the strength ratio of freeze-thaw splitting in cryogenic area.

The residual strength ratio of freeze-thaw splitting is calculated by the following formula: 


$$
\mathrm{TSR}=\frac{R_{T 2}}{\mathrm{R}_{\mathrm{T} 1}} \times 100
$$

In the formula: TSR--the residual strength ratio of freeze-thaw splitting, \%;

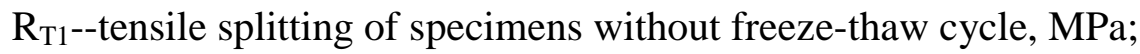

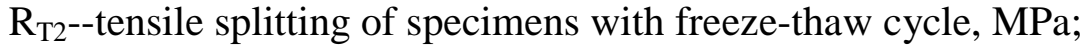

$\mathrm{Pn}$--the maximum value of the test load of specimen, $\mathrm{N}$;

$\mathrm{H}-$-specimen height.

In this study, when the conventional freezing and thawing splitting tests were carried out, the specimens were immersed in different concentrations of sodium sulfate solution for 60 hours after compaction, and then set up for about 12 hours in the room. The freeze-thaw splitting test was carried out according to the method of "Highway Engineering Asphalt and Asphalt Mixture Test Rules". The test results are shown in Table 3-Table 7 on the following page.

Table 3 Split test results of unsoaked specimens

\begin{tabular}{|c|c|c|c|c|c|c|}
\hline & $\begin{array}{l}\text { Sample } \\
\text { number }\end{array}$ & $\begin{array}{l}\text { Maximum } \\
\text { test load } \\
(\mathrm{KN})\end{array}$ & $\begin{array}{l}\text { Specimen } \\
\text { height } \\
(\mathbf{m m})\end{array}$ & $\begin{array}{l}\text { Splitting } \\
\text { tensile } \\
\text { strength } \\
(\mathrm{MPa})\end{array}$ & $\begin{array}{c}\text { Avera } \\
\text { ge } \\
\text { value }\end{array}$ & $\begin{array}{c}\text { Strengt } \\
\text { h ratio } \\
(\%)\end{array}$ \\
\hline \multirow{8}{*}{ 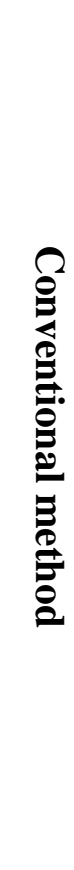 } & $\begin{array}{c}\text { Unfreeze-tha } \\
\text { w- } 1\end{array}$ & 5.3 & 63.95 & 0.521 & \multirow{4}{*}{0.521} & \multirow{8}{*}{79.46} \\
\hline & $\begin{array}{c}\text { Unfreeze-tha } \\
\mathbf{w}-2\end{array}$ & 5.75 & 63.11 & 0.573 & & \\
\hline & $\begin{array}{c}\text { Unfreeze-tha } \\
\text { w- } 3\end{array}$ & 4.25 & 63.57 & 0.420 & & \\
\hline & $\begin{array}{c}\text { Unf reeze-tha } \\
\text { w-4 }\end{array}$ & 5.69 & 63.0 & 0.568 & & \\
\hline & $\begin{array}{c}\text { Freeze-thaw- } \\
1\end{array}$ & 4.04 & 62.84 & 0.404 & \multirow{4}{*}{0.414} & \\
\hline & $\begin{array}{c}\text { Freeze-thaw- } \\
2\end{array}$ & 4.57 & 63.43 & 0.453 & & \\
\hline & $\begin{array}{c}\text { Freeze-thaw- } \\
3\end{array}$ & 4.2 & 63.0 & 0.419 & & \\
\hline & $\begin{array}{c}\text { Freeze-thaw- } \\
4\end{array}$ & 3.86 & 63.63 & 0.381 & & \\
\hline
\end{tabular}

Table 4 Splitting test results of soaking specimens in $3 \%$ sodium sulfate solution

\begin{tabular}{|c|c|c|c|c|c|c|}
\hline & $\begin{array}{l}\text { Sample } \\
\text { number }\end{array}$ & $\begin{array}{l}\text { Maximum } \\
\text { test load } \\
(\mathrm{KN})\end{array}$ & $\begin{array}{l}\text { Specimen } \\
\text { height } \\
(\mathrm{mm})\end{array}$ & $\begin{array}{l}\text { Splitting } \\
\text { tensile } \\
\text { strength } \\
(\mathrm{MPa})\end{array}$ & $\begin{array}{c}\text { Avera } \\
\text { ge } \\
\text { value }\end{array}$ & $\begin{array}{c}\text { Strengt } \\
\text { h ratio } \\
(\%)\end{array}$ \\
\hline \multirow{4}{*}{$\begin{array}{l}\text { Soak } \\
\text { in } 3 \% \\
\text { sodiu } \\
\text { m } \\
\text { sulfat } \\
\text { e } \\
\text { soluti }\end{array}$} & $\begin{array}{c}\text { Unfreeze-tha } \\
\text { w- } 1\end{array}$ & 4.54 & 62.48 & 0.457 & \multirow[t]{4}{*}{0.509} & \multirow{4}{*}{77.6} \\
\hline & $\begin{array}{c}\text { Unfreeze-tha } \\
\text { w-2 }\end{array}$ & 4.88 & 63.54 & 0.483 & & \\
\hline & $\begin{array}{c}\text { Unfreeze-tha } \\
\text { w-3 }\end{array}$ & 5.75 & 62.86 & 0.575 & & \\
\hline & Unfreeze-tha & 5.32 & 64.12 & 0.522 & & \\
\hline
\end{tabular}




\begin{tabular}{|c|c|c|c|c|c|}
\hline \multirow{5}{*}{$\begin{array}{l}\text { on for } \\
60 \\
\text { hours }\end{array}$} & $\mathbf{w}-4$ & & & & \\
\hline & $\begin{array}{c}\text { Freeze-thaw- } \\
1\end{array}$ & 4.07 & 63.34 & 0.404 & \multirow{4}{*}{0.395} \\
\hline & $\begin{array}{c}\text { Freeze-thaw- } \\
2 \\
\end{array}$ & 3.96 & 62.98 & 0.395 & \\
\hline & $\begin{array}{c}\text { Freeze-thaw- } \\
3\end{array}$ & 3.64 & 64.16 & 0.357 & \\
\hline & $\begin{array}{c}\text { Freeze-thaw- } \\
4\end{array}$ & 4.19 & 62.22 & 0.423 & \\
\hline
\end{tabular}

Table 5 Splitting test results of immersion specimens in $6 \%$ sodium sulfate solution

\begin{tabular}{|c|c|c|c|c|c|c|}
\hline & $\begin{array}{l}\text { Sample } \\
\text { number }\end{array}$ & $\begin{array}{l}\text { Maximu } \\
\text { m test } \\
\operatorname{load}(\mathrm{KN})\end{array}$ & $\begin{array}{l}\text { Specime } \\
\text { n height } \\
(\mathrm{mm})\end{array}$ & $\begin{array}{l}\text { Splitting } \\
\text { tensile } \\
\text { strength } \\
(\mathrm{MPa})\end{array}$ & $\begin{array}{c}\text { Avera } \\
\text { ge } \\
\text { value }\end{array}$ & $\begin{array}{c}\text { Strengt } \\
\mathbf{h} \text { ratio } \\
(\%)\end{array}$ \\
\hline \multirow{8}{*}{$\begin{array}{l}\text { Soak } \\
\text { in } 6 \% \\
\text { sodiu } \\
\mathrm{m} \\
\text { sulfat } \\
\text { e } \\
\text { soluti } \\
\text { on for } \\
60 \\
\text { hours }\end{array}$} & $\begin{array}{c}\text { Unfreeze-tha } \\
\text { w-1 }\end{array}$ & 4.44 & 62.38 & 0.447 & \multirow[t]{4}{*}{0.507} & \multirow{8}{*}{80.67} \\
\hline & $\begin{array}{c}\text { Unfreeze-tha } \\
\text { w-2 }\end{array}$ & 5.02 & 63.84 & 0.494 & & \\
\hline & $\begin{array}{c}\text { Unfreeze-tha } \\
\text { w-3 }\end{array}$ & 5.95 & 62.92 & 0.595 & & \\
\hline & $\begin{array}{c}\text { Unfreeze-tha } \\
\text { w-4 }\end{array}$ & 4.92 & 62.93 & 0.492 & & \\
\hline & $\begin{array}{c}\text { Freeze-thaw- } \\
1\end{array}$ & 4.12 & 63.16 & 0.41 & \multirow[t]{4}{*}{0.409} & \\
\hline & $\begin{array}{c}\text { Freeze-thaw- } \\
2 \\
\end{array}$ & 4.16 & 62.82 & 0.416 & & \\
\hline & $\begin{array}{c}\text { Freeze-thaw- } \\
3\end{array}$ & 3.5 & 64.1 & 0.343 & & \\
\hline & $\begin{array}{c}\text { Freeze-thaw- } \\
4\end{array}$ & 4.61 & 62.25 & 0.466 & & \\
\hline
\end{tabular}

Table 6 Splitting test results of soaking specimens in 10\% sodium sulfate solution

\begin{tabular}{|c|c|c|c|c|c|c|}
\hline & $\begin{array}{l}\text { Sample } \\
\text { number }\end{array}$ & $\begin{array}{l}\text { Maximu } \\
\text { m test } \\
\operatorname{load}(\mathrm{KN})\end{array}$ & $\begin{array}{l}\text { Specimen } \\
\text { height } \\
(\mathbf{m m})\end{array}$ & $\begin{array}{l}\text { Splitting } \\
\text { tensile } \\
\text { strength } \\
(\mathrm{MPa})\end{array}$ & $\begin{array}{c}\text { Avera } \\
\text { ge } \\
\text { value }\end{array}$ & $\begin{array}{c}\text { Strengt } \\
\text { h ratio } \\
(\%)\end{array}$ \\
\hline \multirow{5}{*}{$\begin{array}{l}\text { Soak } \\
\text { in } \\
10 \% \\
\text { sodiu } \\
\mathrm{m} \\
\text { sulfat } \\
\text { e } \\
\text { soluti } \\
\text { on for }\end{array}$} & $\begin{array}{c}\text { Unfreeze-tha } \\
\mathbf{w}-1\end{array}$ & 5.15 & 64.22 & 0.504 & \multirow[t]{4}{*}{0.469} & \multirow{5}{*}{74.63} \\
\hline & $\begin{array}{c}\text { Unfreeze-tha } \\
\text { w-2 }\end{array}$ & 4.61 & 64.28 & 0.451 & & \\
\hline & $\begin{array}{c}\text { Unfreeze-tha } \\
\text { w-3 } \\
\end{array}$ & 4.93 & 63.44 & 0.489 & & \\
\hline & $\begin{array}{c}\text { Unfreeze-tha } \\
\text { w-4 }\end{array}$ & 4.42 & 64.39 & 0.432 & & \\
\hline & $\begin{array}{c}\text { Freeze-thaw- } \\
1 \\
\end{array}$ & 3.9 & 62.71 & 0.391 & 0.35 & \\
\hline
\end{tabular}




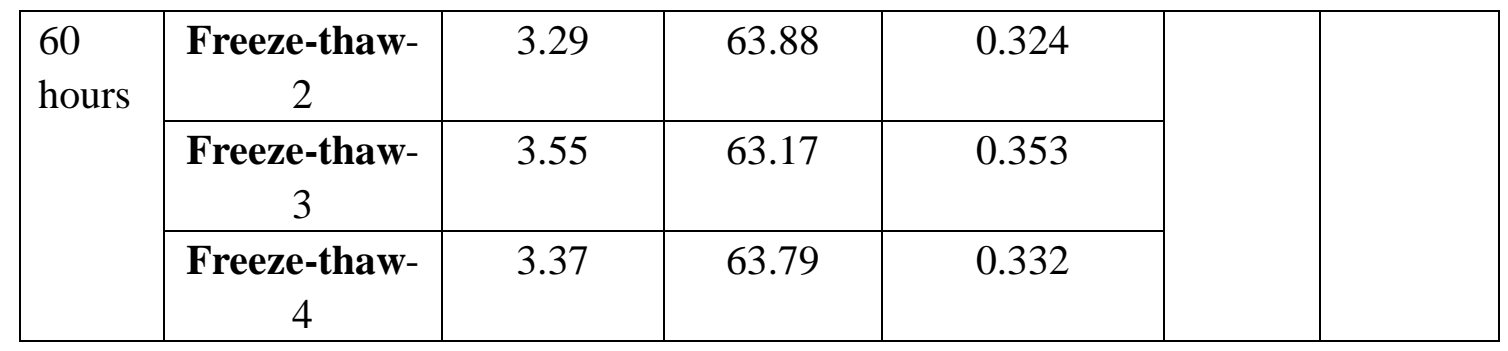

Table 7 Splitting test results of soaking specimens in $15 \%$ sodium sulfate solution

\begin{tabular}{|c|c|c|c|c|c|c|}
\hline & $\begin{array}{l}\text { Sample } \\
\text { number }\end{array}$ & $\begin{array}{l}\text { Maximu } \\
\text { m test } \\
\operatorname{load}(\mathrm{KN})\end{array}$ & $\begin{array}{l}\text { Specimen } \\
\text { height } \\
(\mathbf{m m})\end{array}$ & $\begin{array}{l}\text { Splitting } \\
\text { tensile } \\
\text { strength } \\
(\mathrm{MPa})\end{array}$ & $\begin{array}{c}\text { Avera } \\
\text { ge } \\
\text { value }\end{array}$ & $\begin{array}{c}\text { Strengt } \\
\text { h ratio } \\
(\%)\end{array}$ \\
\hline \multirow{8}{*}{$\begin{array}{l}\text { Soak } \\
\text { in } \\
15 \% \\
\text { sodiu } \\
\mathrm{m} \\
\text { sulfat } \\
\mathrm{e} \\
\text { soluti } \\
\text { on for } \\
60 \\
\text { hours }\end{array}$} & $\begin{array}{c}\text { Unfreeze-tha } \\
\text { w-1 } \\
\end{array}$ & 4.32 & 63.15 & 0.43 & \multirow{4}{*}{0.496} & \multirow{8}{*}{69.56} \\
\hline & $\begin{array}{c}\text { Unfreeze-tha } \\
\text { w-2 }\end{array}$ & 5.66 & 63.12 & 0.564 & & \\
\hline & $\begin{array}{c}\text { Unfreeze-tha } \\
\text { w-3 } \\
\end{array}$ & 5.37 & 64.09 & 0.527 & & \\
\hline & $\begin{array}{c}\text { Unfreeze-tha } \\
\text { w-4 }\end{array}$ & 4.66 & 63.34 & 0.463 & & \\
\hline & $\begin{array}{c}\text { Freeze-thaw- } \\
1 \\
\end{array}$ & 3.47 & 63.77 & 0.342 & \multirow[t]{4}{*}{0.345} & \\
\hline & $\begin{array}{c}\text { Freeze-thaw- } \\
2 \\
\end{array}$ & 3.85 & 64.21 & 0.377 & & \\
\hline & $\begin{array}{c}\text { Freeze-thaw- } \\
3 \\
\end{array}$ & 3.51 & 63.81 & 0.346 & & \\
\hline & $\begin{array}{c}\text { Freeze-thaw- } \\
4\end{array}$ & 3.22 & 64.41 & 0.314 & & \\
\hline
\end{tabular}

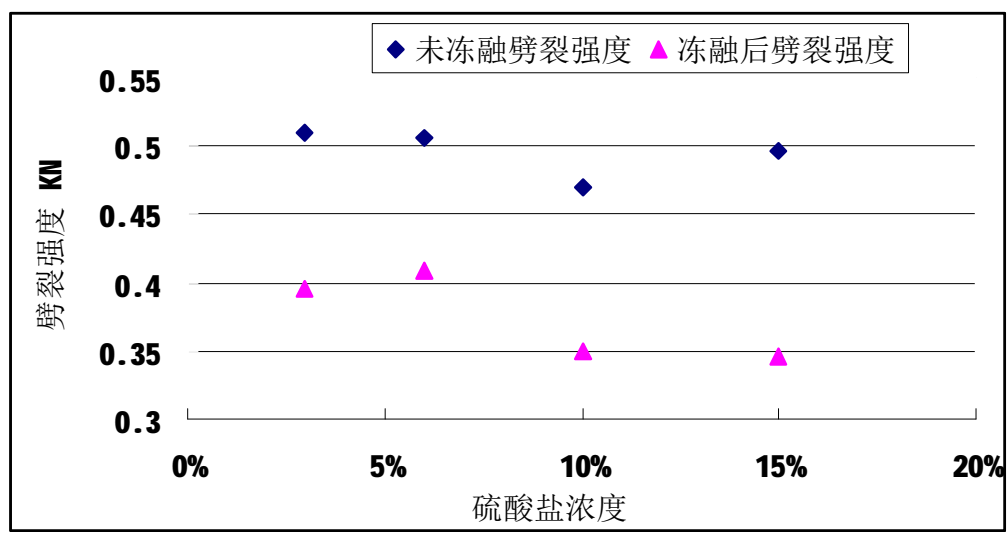

Fig. 3 Relationship between splitting strength and sulfate concentration before and after freeze-thawing 


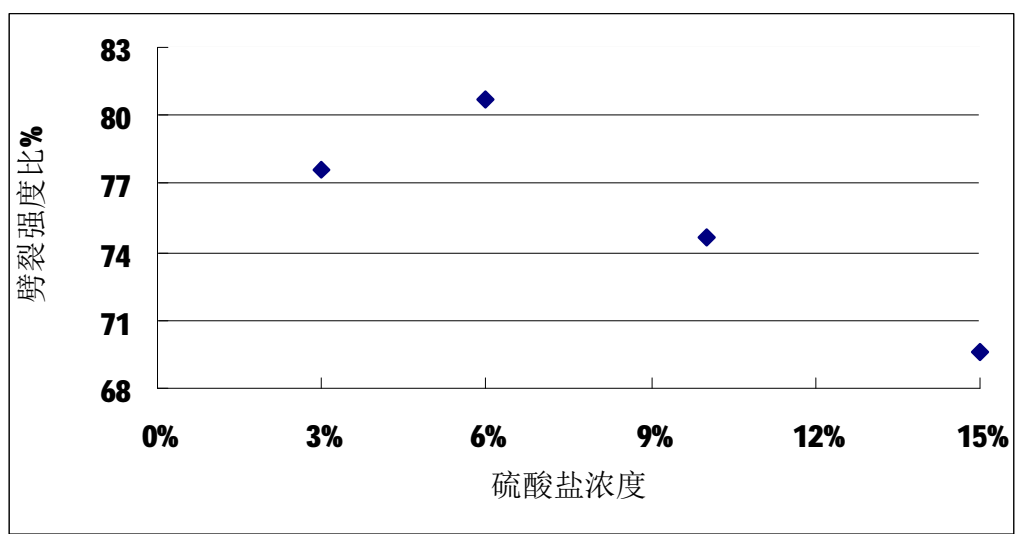

Fig. 4 Variation of splitting strength ratio at different sulfate concentrations

From Fig.3 and Fig.4, combined with experimental data, it can be concluded that:

1) The splitting strength of asphalt mixture without sulfate erosion is $0.521 \mathrm{KN}$ and $0.44 \mathrm{KN}$ before and after freeze-thawing, and the calculated splitting strength ratio is $79.46 \%$, which meets the requirements of specifications. With the increase of sulfate concentration, the splitting strength of unfreeze-thawing specimens and the splitting strength after freeze-thawing of the Marshall specimens with sulfate erosion decreases with the increase of sulfate concentration, which indicates that the sulfate erosion reduced the splitting strength of asphalt mixture.

2) The splitting strength ratio decreases with the increase of concentration under the erosion of sulfate solution of different concentrations before and after freeze-thawing. The water stability test of asphalt mixture is required that the splitting strength ratio should not be less than $75 \%$ or $70 \%$. When the sulphate concentration reaches $15 \%$ and the splitting strength ratio is $69.56 \%$, it can not meet the requirements.

\section{Conclusion}

This study takes the sulfate as the main representative to discuss the variation of the stability of asphalt mixture surface in saline soil area under salt erosion based on the special test method and the evaluation index. On the basis of the existing test methods, considering the origin and formation of the salt content of the pavement surface mixture in the saline soil area, the method of soaking the specimen is used to erode the specimen, and the different erosion effect of the salt to the asphalt mixture is realized. Based on the data analysis of immersion Marshall test and freeze-thaw splitting test, it is clear that the water stability of asphalt pavement is seriously damaged by sulfate erosion in saline soil area in long-term.

\section{Reference}

[1] Zheng Yuxin. Xinjiang Gan- Mo highway saline soil compaction test research [D], Railway Construction,2013, 23(2) 140 142

[2] Mohamed M.EI-Basyouny, Matthew W.Witczak Verification of the Calibrated Fatigue Cracking Models for the 2002 Design Guide.2005 Annual Meeting and Technical Sessions March 7-9,2005. Paper No.AAPT-017

[3] S.Hallberg. The Adhesion of Bituminous Binders and Aggregates in the Presence of Water[R].Statens Vaginstitut, Stockholm, Meddeland, 78, 1950.

[4] KD.Stuart.Moisture Damage in Asphalt Mixtures-A State-of-the Art Report[R].FHWA,Report FHWA-RD-90-019,Aug.1990.

[5] Research on the mix design of the hot in-place recycling technology and its application [D], Advances in Engineering Research (AER), volume 135 (ICCTE 2017), 49 51 